\title{
Terrapene nelsoni Stejneger 1925 - Spotted Box Turtle, Tortuga de Chispitas, Tortuga de Monte
}

\author{
James R. Buskirk ${ }^{1}$ and Paulino Ponce-Campos ${ }^{2}$ \\ ${ }^{1}$ San Antonio Health Center, 1030 International Blvd., Oakland, California 94606 USA [jrbuskirk@aol.com]; \\ ${ }^{2}$ Bosque Tropical, A.C. Misión San Antonio, Torre 4a, Depto. 2, Col. Plaza Guadalupe, \\ Zapopan, Jalisco 45030, Mexico [poncecp@hotmail.com]
}

\begin{abstract}
Summary. - Known from only a handful of localities in the Sierra Madre Occidental of western Mexico, the Spotted Box Turtle, Terrapene nelsoni (Family Emydidae), remains one of the least known chelonian species of North America. Only at the type locality and at one site in Chihuahua have more than four specimens been recorded, most other records consisting of incidental finds or acquisition of solitary specimens. Population density, natural history, and reproductive parameters are thus not understood, and even the favored microhabitat of the species is uncertain. Often the habitat is of difficult access, precipitous, and the turtles themselves seem to have a short activity season, coinciding with the summer monsoon. Most literature on the species is limited to physical description of specimens, on the basis of which two subspecies have been recognized. Based on comparisons of 32 morphological features, the most recent phylogenetic analysis of genus Terrapene has confirmed the close relationship of $T$. nelsoni to $T$. ornata, to which it is parapatric in the northern portion of its range. No threats to the species are currently known, and it is classified as Data Deficient on the IUCN Red List. Monitoring for the possibility of an international pet trade developing would be advisable.

Distribution. - Mexico. Records exist from five Mexican states: Chihuahua, Jalisco, Nayarit, Sinaloa, and Sonora, with those from the latter outnumbering all the others combined. All localities are restricted to the Pacific versant of the Sierra Madre Occidental in montane regions from approximately $450 \mathrm{~m}$ to at least $1640 \mathrm{~m}$. It is the only Terrapene species found to the west of the Cordillera. More than $200 \mathrm{~km}$ separate the southernmost record for the species (near Guachinango, Jalisco) from the type locality (Pedro Pablo, Nayarit), which in turn lies more than 600 km southeast of the nearest confirmed locality to the north (near Terreros, Sinaloa) suggesting that the species is either more widespread than documented, or that its range is fragmented.

SynONYMy. - Terrapene nelsoni Stejneger 1925.

SubSPECIES.-Two subspecies are currently recognized: Terrapene nelsoni nelsoni (Southern Spotted Box Turtle) (distribution: Nayarit, Jalisco, and southern Sinaloa, Mexico) and Terrapene nelsoni klauberi (Northern Spotted Box Turtle) (synonymy: Terrapene klauberi Bogert 1943) (distribution: Sonora, Chihuahua, and northern Sinaloa, Mexico).

STATUS. - IUCN 2011 Red List: Data Deficient (DD, assessed 1996, needs updating); CITES: Appendix II, as Terrapene spp.; Mexico: Pr (2.2.4., Subject to Special Protection).
\end{abstract}

Taxonomy. - Described as Terrapene nelsoni by Stejneger in 1925 from a single specimen collected by Nelson and Goldman in 1897, the Spotted Box Turtle remained otherwise unknown to the scientific community until four more were collected in 1941 in southern Sonora, but described by Bogert (1943) as a new species, Terrapene klauberi. However, Bogert noted a similarity between his type series of klauberi and the holotype of nelsoni, and suggested that the two geographical forms might be conspecific. His insight was remarkable, as not having examined the holotype of $T$. nelsoni, he based his comparison partially on a miscaptioned photo of $T$. goldmani $(=$ T. carolina mexicana $)$ published by Ditmars (1934,Fig. 33). This lapsus was first pointed out by Shaw (1952), who examined the holotype of nelsoni as well as 7 specimens of klauberi, of which four ( 2 males and 2 females) were living at the time. The single available specimen of T. nelsoni, the holotype USNM 45652, determined by him to be a male, was so distinct in appearance from any of the Sonoran klauberi, that Shaw strongly upheld the hypothesis that each represented a distinct species.

Mertens and Wermuth (1955) declared nelsoni and klauberi to be conspecific geographical subspecies based on perceived similarity. However, they later reversed themselves and listed both taxa as full species (Wermuth and Mertens 1961). Their dichotomous key to the genus Terrapene separates nelsoni from klauberi entirely on the basis of what are actually secondary sexual characteristics - as Bogert (1943) had done. Milstead and Tinkle (1967), without reference to Wermuth and Mertens, again declared a southern ( $T$. nelsoni nelsoni ) and northern (T.n. klauberi ) subspecies, respectively, based on a number of morphological traits.

The only known museum specimen of T. nelsoni in Europe by the mid-20th century had been presented to the MNHN in Paris in 1898, having been collected in the 


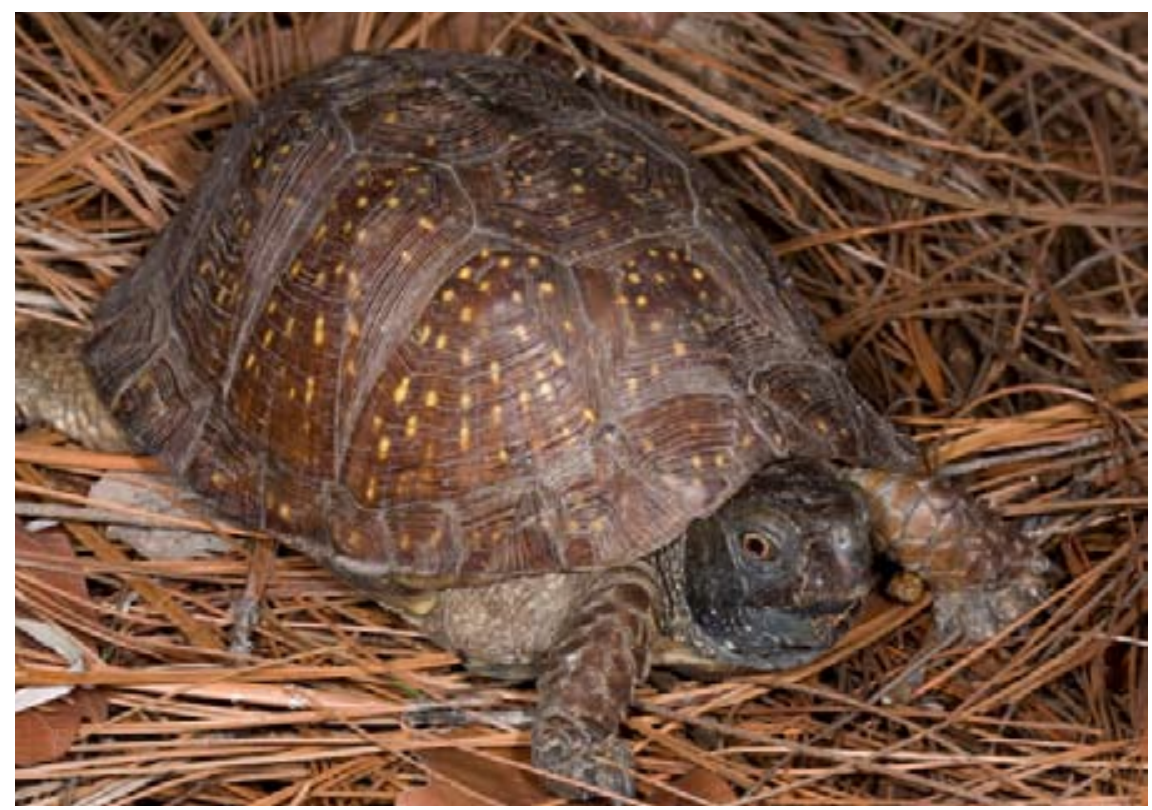

Figure 1. Adult male Terrapene nelsoni klauberi, near Yecora, Sonora. Photo by Matt Cage.

"Sierra de Nayarit, partie occidentale" by Léon Diguet a year or two earlier (Mocquard 1899). It was not mentioned in the literature again until Smith and Smith (1979). This specimen, originally bearing the label Cistudo carolina, had been misplaced until 2001 (figured in Devaux and Buskirk 2001). Significantly, this heavily spotted specimen appears to have been a female whereas the unpatterned holotype (miscaptioned Fig. 36 of Ditmars 1934, better illustrated by Milstead 1969) is a male (Shaw 1952). Had Diguet's female specimen from Nayarit been declared the holotype of a new species, or been available for comparison to Stejneger's (1925) holotype, the nomenclatural history of Terrapene nelsoni surely would have evolved differently. Sexual dimorphism within Terrapene nelsoni is much more impressive than reported distinctions between the regional subspecies (Buskirk 2002).

Bogert (1943) suspected that T. klauberi was closely related to both ornata and nelsoni, but called for a larger sample for comparison than that available to him. Milstead

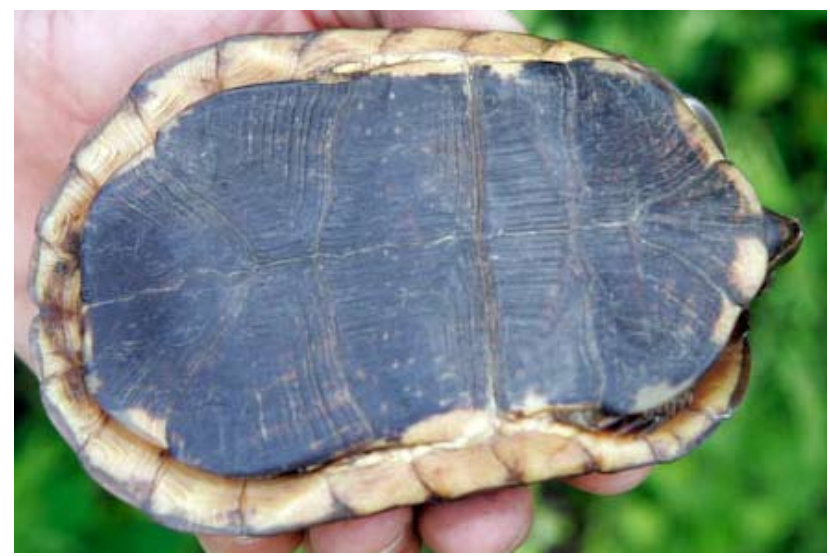

Figure 2. Subadult male Terrapene nelsoni klauberi, west of Yecora, Sonora. Photo by Young Cage. and Tinkle (1967) described an "Ornata Group" and a "Carolina Group" within the genus Terrapene based on 12 morphological traits, and considered ornata and nelsoni to be sister species. Milstead (1969) expanded the criteria to 16 traits. The first workers to examine several (37) nelsoni from the type locality, as well as 13 specimens of klauberi from Sonora and the single Sinaloan specimen (a carapace and plastron only), Milstead and Tinkle (1967) further speculated on the common ancestry of T. ornata and T. nelsoni-T. klauberi, possibly through the extinct $T$. ornata longinsulae. That both recent members of the Ornata Group tend to inhabit savanna habitats, rather than forests or wetlands, was cited by them as further evidence of their close relationship. Milstead and Tinkle found little but plastral scute ratios and the contour of the first vertebral scute to distinguish between the southern and northern races of the Spotted Box Turtle, and limited their discussion of sexual dimorphism to the degree of flaring of the posterior marginals (more marked in the larger southern sample) and the tendency for females to be

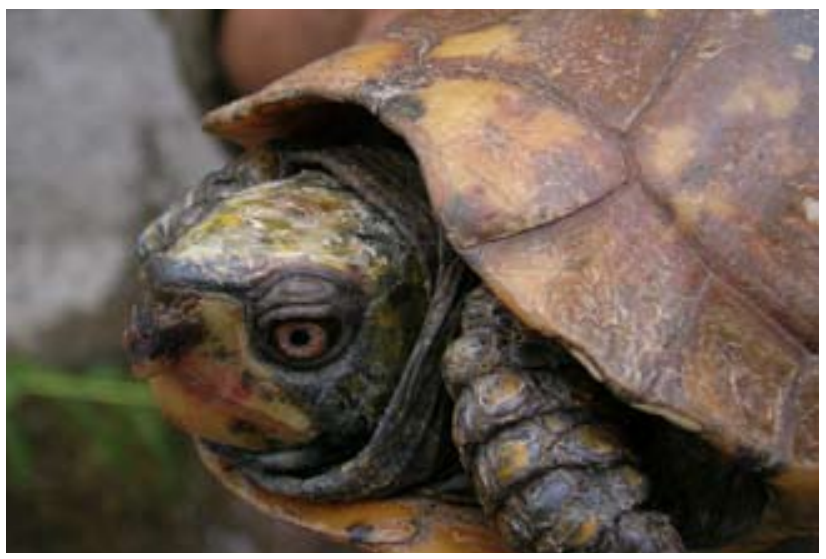

Figure 3. Old adult male Terrapene nelsoni klauberi, Rio Aros, Sonora. Photo by Michael S. Bogle. 


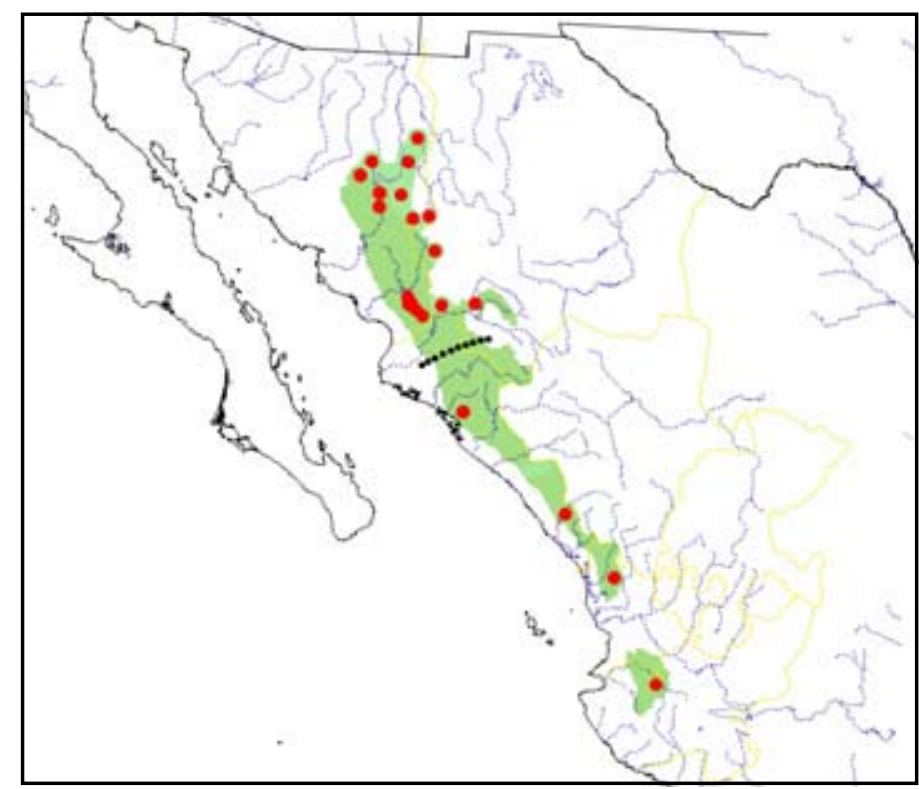

Figure 4. Distribution of Terrapene nelsoni in Mexico in the states of Chihuahua, Jalisco, Nayarit, Sinaloa, and Sonora (state boundaries in yellow). Southern (T.n. nelsoni) and Northern (T.n. klauberi) subspecies apparently delimited somewhere in the vicinity of the dotted black line. Red dots = museum and literature occurrence records of native populations based on Iverson (1992), plus more recent and authors' data; green shading = projected native distribution based on GIS-defined hydrologic unit compartments (HUCs) constructed around verified localities and then adding HUCs that connect known point localities in the same watershed or physiographic region, and similar habitats and elevations as verified HUCs (Buhlmann et al. 2009), and adjusted based on authors' data.

more rounded, thus resembling ornata. They suggested that unspotted specimens might occur in the Nayarit population. Possibly they had not yet seen the unspotted male holotype, USNM 46252, at the time of writing.

Smith and Smith (1979) concurred with the subspecific division but pointed out that until more specimens were recorded and assessed from the large area separating the northern from the southern specimens, this separation was only tentative. They agreed with the placement of T.nelsoni within the Ornata Group alongside T. ornata.

Minx (1996) upheld the close relationship between nelsoni and klauberi based on the analysis of 32 morphological characters, but disputed whether nelsoni was derived either from ornata or longinsulae, without discarding his belief in their shared ancestry. He was unable to compare all characters between nelsoni nelsoni ( 25 examined) and nelsoni klauberi
(12 examined), and his findings regarding co-ossification of the carapace in the latter were inconclusive. Minx made no strong statement affirming the validity of the subspecies of T.nelsoni and had little to say concerning sexual dimorphism within the taxon. However, he was the first to note the presence of "bulbous shields," or hypertrophied forelimb scales, on male nelsoni everywhere, a unique trait within the genus Terrapene (Minx 1996, Buskirk 2002).

Description. - Mature specimens of T. nelsoni fall within the dimensional range of adults of the more familiar T.carolina, excepting subspecies T.c.major. Milstead (1969) provided $134 \mathrm{~mm}$ as the average straight line carapace length (CL) of southern adults examined, the maximum being 146 $\mathrm{mm}$. Northern specimens (T.n. klauberi) averaged $131 \mathrm{~mm}$ $\mathrm{CL}$, with the largest measuring $151 \mathrm{~mm}$. The CL of a living male Spotted Box Turtle from southern Sonora measured by
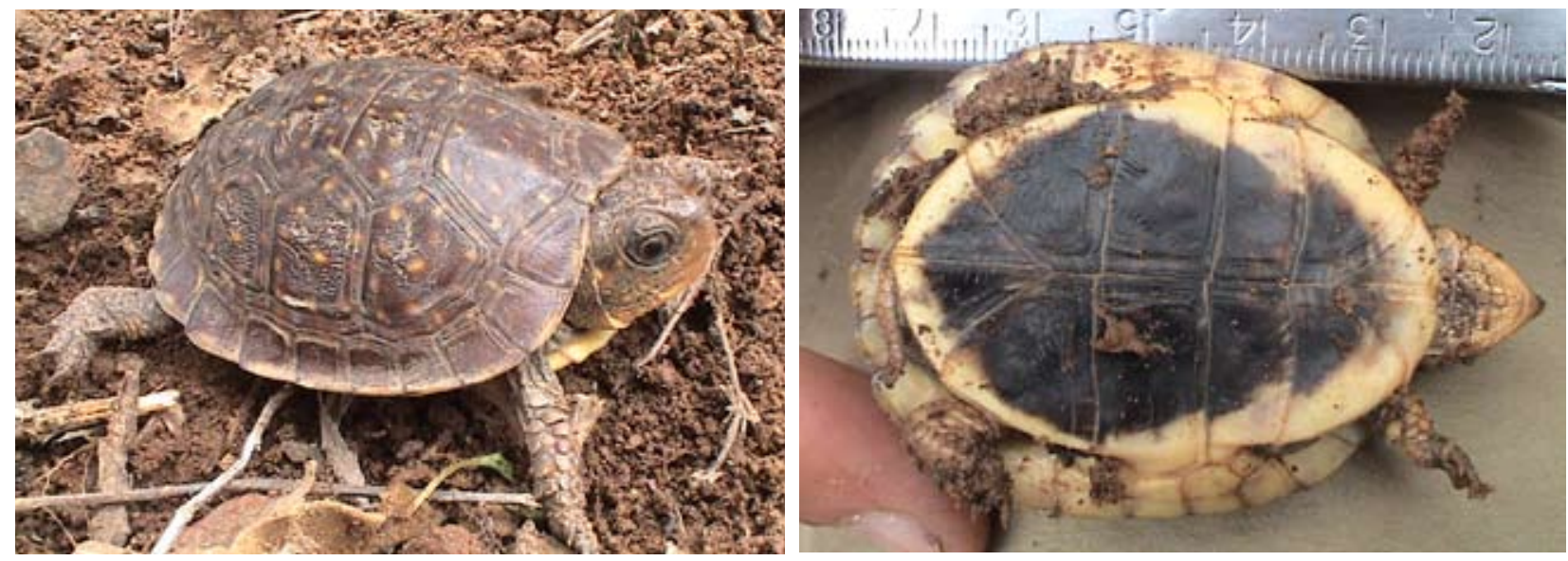

Figure 5. Post-hatchling Terrapene nelsoni klauberi, Palo Amarillo, Uruachi, Chihuahua. Photos by Paulino Ponce-Campos. 

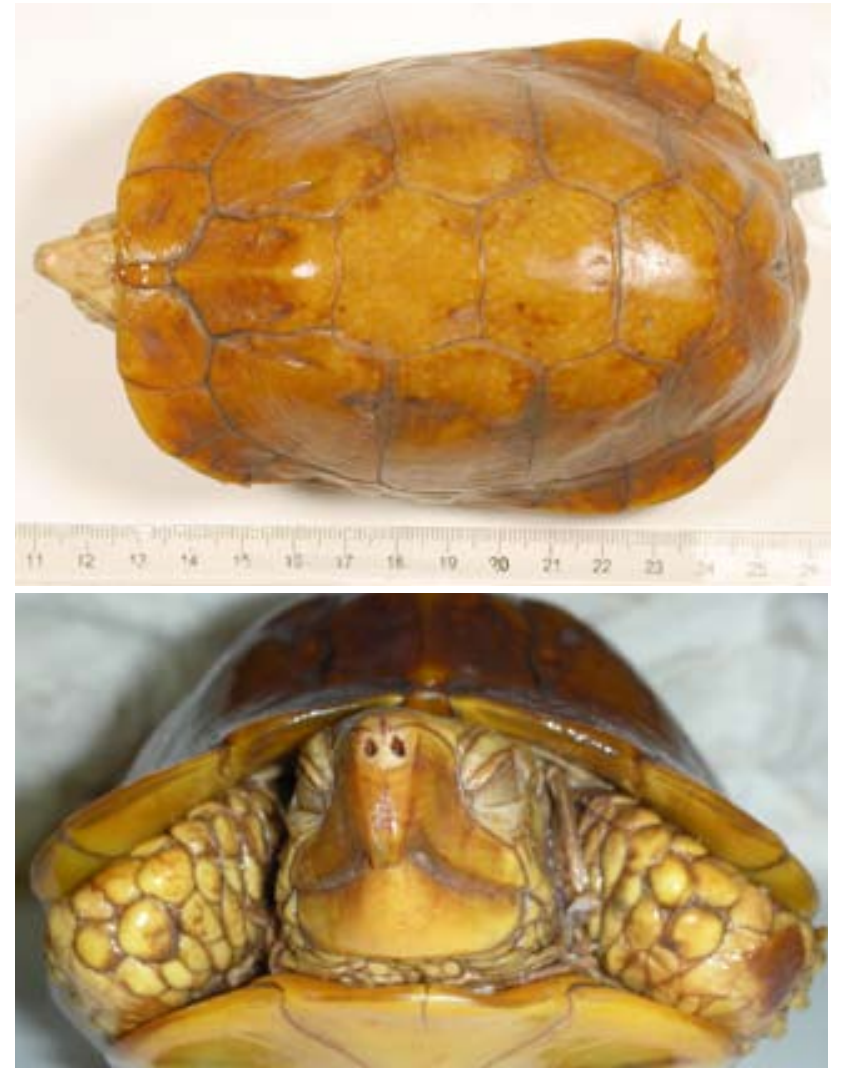

Figure 6. Preserved adult male Terrapene nelsoni nelsoni, the holotype (USNM 46252) from Pedro Pablo, Nayarit. Photos by James Poindexter.

the first author was $159 \mathrm{~mm}$ (Buskirk 2002). Some degree of dorsal flattening is present, and there may be a central keel or remnants thereof on vertebrals 2 through 4 , as well as faint lateral keels. The outline of the carapace may be elongate, oval, or roundish. To a varying extent, the posterior marginals may be flared in males, particularly among southern turtles (Milstead 1969, Dodd 2001).

The overall coloration of the carapace is variable, from nearly black to greenish brown, tan, or beige. Yellow or "coffee colored" spots (Milstead 1969) are usually present on the carapace and soft parts but may be absent in males (see below). The spots are variable in size from one specimen to the next, but tend to be of nearly uniform size per individual. All 30 adult specimens examined by Lemos-Espinal (2005)

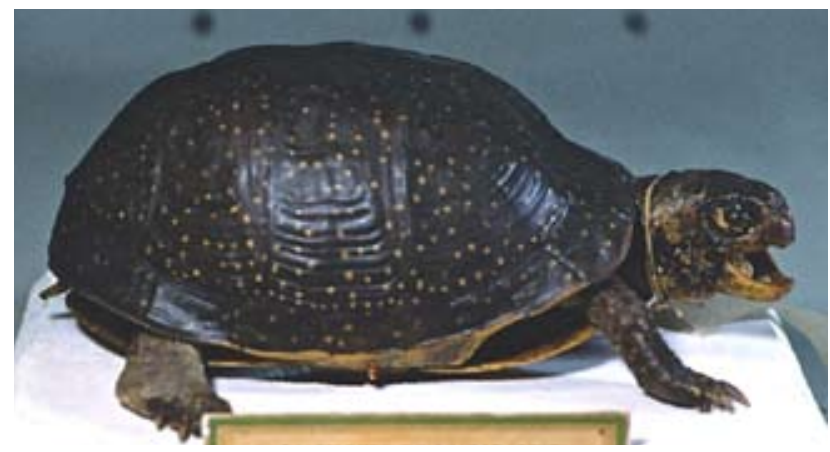

Figure 7. Stuffed adult female Terrapene nelsoni nelsoni, Diguet's 1897 specimen from Sierra de Nayarit, Nayarit, at the MNHN, Paris. Photo by Bernard Devaux. in southwestern Chihuahua were spotted. The predominant color of the soft parts is non-descript brownish or grayish, tending to be pale on the flexor surfaces of the limbs and throat. On adult males, the bulbous shields of the forelimbs are sometimes partially absent, as on the left forelimb of the holotype USNM 45652, presumably from having been bitten off by other males. The plastron is often mostly black containing yellow-spotted areas, except the periphery, which, in sharp contrast, is yellowish. The periphery of the plastron and underside of the marginals of a female photographed by Richard Bartlett near Álamos, Sonora, are nearly orange, rather than yellow. On the plastron of the holotype of T.n. nelsoni (USNM 46252), the dark pigmentation is greatly reduced, especially anteriorly, and the spots on the carapace are few and very faint at best.

A unique physical trait of the species is the ability of adults of both sexes to rotate the innermost hind claw, a trait largely restricted to males of T.ornata (Legler 1960). The first claw is enlarged in nelsoni as in ornata males, presumably playing a similar adjunct role in mating, but is not enlarged in nelsoni females, in whom nonetheless it is hypermobile (Minx 2009).

Only one living post-hatchling has been recorded (Franklin and Killpack 2009, Ponce-Campos and Buskirk 2010). Other figures of this same post-hatchling found and photographed by Paulino Ponce-Campos on 1 July 2006, besides those appearing in the work of Franklin and Killpack (2009), indicated a CL of about $42 \mathrm{~mm}$. At the time of hatching, by extrapolation, the CL would have just exceeded 35 $\mathrm{mm}$. Like the neonates of T. ornata and T. carolina bauri, but unlike neonates of most Terrapene taxa, the neonate of $T$. nelsoni resembles the adult. The brownish carapace may bear several tiny yellow spots, or as few as one, on each large dorsal scute, and tiny spots are also present on the brownish extensor surfaces of the limbs and on the head. The chin is pale, as to a lesser extent are the flexor surfaces of the limbs. The overall contour of a specimen just beginning to exhibit growth is nearly round, and the middorsal keel is prominent from the middle of the first to the rear of the fourth vertebral scute. The plastron bears a single dark figure extending nearly to the edges, unusual among neonate Terrapene, which, like the undersides of the marginals, are pale yellow. The posterior edge of the

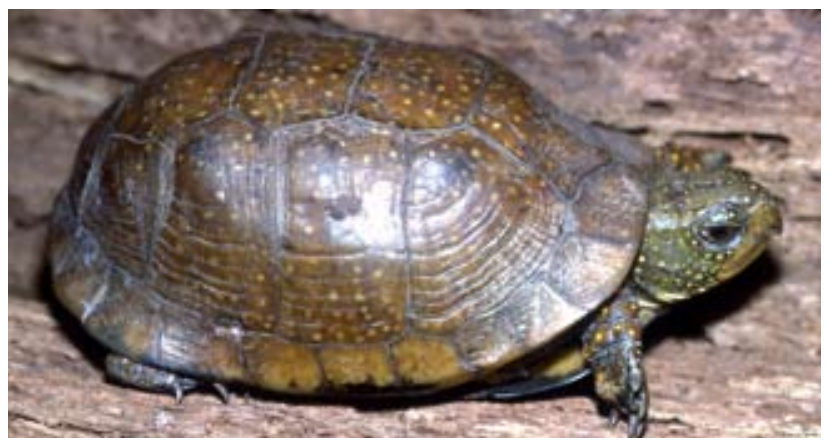

Figure 8. Adult Terrapene nelsoni nelsoni from Nayarit. Photo by John Iverson. 
carapace is serrated to a degree greater than in neonates of other Terrapene taxa.

Geographic Variation. - The taxonomic history of $T$. nelsoni reveals that the division of the species into a northern subspecies (klauberi-from Sonora, Chihuahua, and northern Sinaloa) and a southern subspecies (nelsoni-from Nayarit, Jalisco, and southern Sinaloa) has been based on comparison between the single holotype (male) of the nominative (southern) form, nelsoni, and four females of the northern form, klauberi. Comparisons of a much larger sample by Milstead and Tinkle (1967) are summarized by Smith and Smith (1979) to yield the following traits allegedly distinguishing the subspecies: 1) carapace dots smaller and more numerous in klauberi; 2) slope of anterior vertebral scute mean $38^{\circ}$ in klauberi, mean $30^{\circ}$ in nelsoni; 3) first vertebral tending to be parallel sided in nelsoni, but much wider anteriorly than posteriorly in klauberi; 4) first vertebral shorter than third vertebral's width in klauberi, equal to third vertebral's width in nelsoni; 5) interhumeral seam mean $16 \%$ of anterior lobe length in nelsoni, $19 \%$ in klauberi; and 6) upper jaw notched in klauberi, not notched in nelsoni.

Only the sixth characteristic may be even somewhat reliable; as some male specimens of nelsoni from the type locality have a notched upper jaw, its validity is also questionable. The remaining traits may in part be ontogenetic, particularly the vertebral scute proportions and shape (older turtles everywhere having a narrower first vertebral). Photographs of live nelsoni from the type locality (Minx 2009) reveal some with carapaces densely spotted with tiny spots, and all but one old-appearing male having a first vertebral scute broader anteriorly than at its junction with the second vertebral. That specimen, and the large-spotted, largest known male specimen of klauberi are figured in Buskirk (2002, figs. 1, 3, 7). In the aggregate, these characteristics may prove to be useless in the identification of subspecies of a Spotted Box Turtle of unknown provenance.

The use of plastron morphology (particularly scute ratios) in chelonian taxonomy, with or without recourse to contemporary biochemical and molecular methods, remains somewhat in vogue (Lovich et al.1991; Bickham etal. 1996), but has not yet been applied to intraspecific variation in $T$. nelsoni.

Sexual Dimorphism. - Shaw (1952) first described differences in the coloration of soft parts between adult male and female T.n. klauberi. Males tend to have unspotted soft parts and heavily pigmented mandibular and maxillary shields, in contrast to these being relatively immaculate in females. Bogert (1943, figs. 1-3) clearly showed the typical appearance of the head of a female T. n. klauberi. Further morphological distinctions of gender were not documented until Minx (1996) highlighted the presence of bulbous, hypertrophied antebrachial scales (shields) on males of both geographic races of $T$. nelsoni. These can be clearly seen in the tiny photograph (Minx 1996, fig. 18A) of a living male specimen from the type locality (Milstead 1969) but not, interestingly, in his views of the male holotype (Minx 1996, figs. 18E, G). Sharper photographs of the holotype of
T. nelsoni, USNM 46252 (see Fig. 6), reveal the presence of large scales on the right antebrachium and their partial absence on the distal left antebrachium, where scarring suggests previous trauma. Captive and wild-caught male T. $n$. klauberi from Sonora have exhibited scarred and extensive scaleless areas on the antebrachia, believed to be from violent fights with other males, as the senior author witnessed between two males from Álamos, Sonora, confined together in 1986.

From examining an admittedly small sample of live specimens of klauberi, Buskirk (2002) amplified the list of dimorphic traits to include males having larger heads than females, a more pronounced maxillary notch, and in living specimens, orange or reddish pigmentation on the mandibular shield, and a red rather than brown iris. Furthermore, some mature males have greatly reduced spotting of the carapace and soft parts, or none. Identifying the gender of an adult specimen from a photograph is fairly straightforward (e.g., the Chihuahua specimen figured in Lemos-Espinal et al. 2004 is a male; see also Devaux and Buskirk 2001). LemosEspinal (2005) did not discuss phenotypic variation, including sexual dimorphism, among the 30 adult specimens that he examined.

Osteology. - The cranial features which distinguish T. nelsoni from other box turtles except ornata include the absence of the zygomatic arch (as well as postorbital process), and an extremely thin postorbital bone (Minx 1996). The skull of one of the paratypes of T. klauberi is figured by Bogert and Oliver (1945). Neural configuration approximates that of T. ornata, the usual formula being 4-8-4-(7,8)-(4,5)-6-7. In common with ornata, in nelsoni the peripheral bones distal to the hinge are relatively thin and outwardly expanded, the length of the scapula roughly equals that of the acromial process, and the most reduced phalangeal formula of the forefeet, 2-2-2-2-2 prevails, whereas that of the hind feet, 2-3-3-3-1 is shared with most other Terrapene taxa except coahuila. Minx (1996) cautioned that the carapace and phalangeal osteology of T. n. klauberi was not evaluated.

Diagnosis. - Taking into account its significant sexual dichromatism and dimorphism, T. nelsoni is unlikely to be confused with the only parapatric box turtle, T.ornata luteola notwithstanding the latter's remarkable phenotypical variability. Rarely absent in unpatterned luteola is some degree of pale radiating markings on a darker plastron, or exceptionally, a largely pale plastron with zonary dark markings. In T. ornata, the highest part of the carapace lies anterior to the hinge (posterior to it in nelsoni), and the dorsal keel is reduced compared with nelsoni (Smith and Smith 1979).

Distribution. - The known range of the Spotted Box Turtle extends from the El Riito drainage near Nácori Chico, Sonora (29.69 N, 108.88 W; S. Jacobs and A. Flesch, pers. comm.) in the northwest, to near Guachinango, Jalisco (20.32 N, 104.15 W) in the southeast. Between these outlying localities, both documented as recently as 2006 , lie vast areas from which no specimens of T. nelsoni are yet known. Perhaps no other Mexican endemic chelonian having such a large area of overall geographical distribution remains 
almost unrecorded from all but a quarter of its documented range, the extent of which occupies the eastern and southern portions of the state of Sonora. Besides the El Riito record (a female, August 2006) a male and female had been found and photographed the previous summer, at different sites several $\mathrm{km}$ to the south along the Río Aros, a larger tributary of the Río Yaqui (O’Brien et al. 2006). These finds, in the course of biological inventories, extend the known range of the species by about 105 and $90 \mathrm{~km}$, respectively, eastnortheast of Matapé (renamed Villa Pesqueiras, approximate geographical coordinates $29^{\circ} 06^{\prime} \mathrm{N}, 109^{\circ} 57^{\prime} \mathrm{W}$ ), the previous northernmost record for the species (Myers 1945).

Aside from the incomplete Terreros specimen (Hardy and McDiarmid 1969), found at $600 \mathrm{~m}$ altitude, a skull in the collection of the Chelonian Research Institute from "80 miles N. Mazatlán" is the only other museum record for the species from the state of Sinaloa (Dodd 2001). However, that imprecise locality may lie in the adjacent state of Durango, in which the species almost surely occurs as well (Smith and Smith 1979). On 3 September 2004, a specimen was observed following an extensive period of rain in northeasternmost Sinaloa near the Chihuahua state line (V. Dinets, pers. comm.). There is a reliable report of its presence near Mesillas, Sinaloa, though the settlement's altitude of only 140 $\mathrm{m}$ is lower than that of any confirmed record for the species. It is unknown how far from that locality a female specimen purchased there in the late 1980s by wildlife traffickers, and smuggled into California, had actually originated. The specimen did not survive long and its remains were discarded.

The recent first records for the species from the states of Chihuahua (Lemos-Espinal and Smith 2002) and Jalisco (Montes-Ontiveros and Ponce-Campos 2006) reflect the efforts of Mexican biologists to document the herpetofauna of remote montane areas, which for the most part had not been surveyed at all, or only during the time of year when box turtles are not active. During the dry season, many parts of the known and presumed range of the species are more easily accessible to humans. Lemos-Espinal (2005) found no box turtles in May, a few weeks prior to the arrival of the summer monsoon in the same hills in which he found 30 turtles during the month of July. His experience was mirrored by that of Minx in Nayarit in 1987, who arrived at the type locality on 27 June, towards the end of five rainless months, and finding the first of many spotted box turtles ten days later following a series of drought-breaking rains (Minx 2009).

Habitat and Ecology. - The altitudinal range of Terrapene nelsoni includes a variety of botanical zones, from neotropical short tree forest and thorn scrub to oak woodland. The female specimen recorded by Myers (1945) had been found in "desert scrub" between 500-641 m above sea level, in a hilly region in which mesquite thicket, neotropical forest, and neotropical deciduous woodland were all present. Throughout the Sierra Madre Occidental, the summer monsoon provides nearly all precipitation and coincides closely with the activity season of the turtle. Acaponeta, Nayarit, about $40 \mathrm{~km}$ west of the type locality, receives an average of $1307 \mathrm{~mm}$ of annual precipitation, $92 \%$ of it between June and September (Anonymous 2009). These are the months during which all living specimens of $T$. nelsoni have been found, although some of the specimens of the type series of klauberi may have been found as late as early October (Bogert and Oliver 1945). According to Minx (2009), activity among Sonora specimens may precede or extend beyond the monsoon season, and at Pedro Pablo, an informant whom he considered reliable declared that the turtles are sometimes seen as late as November. There are no data to corroborate these claims.

The post-hatchling specimen in Chihuahua (PonceCampos and Buskirk 2010) was found at an elevation of 1640 $\mathrm{m}$ in a transition zone between oak woodland and acacias, in secondary vegetation. Some specimens have been found in steep areas where there was little level ground other than the road on which those who encountered the turtles had been traveling. Being terrestrial, Spotted Box Turtles may have a propensity to wander and thus turn up in different habitats during their seasonal activity. The altitude of the type locality, Pedro Pablo, Nayarit, is given as 2500 feet $(758 \mathrm{~m})$ by Stejneger (1925), but the area includes hills rising from a plateau - the turtles chiefly being found in the former (Minx 2009). However, other sources (Goldman 1951, Smith and Smith 1979) provide an elevation figure for Pedro Pablo in excess of $1000 \mathrm{~m}$, recapitulating the possible confusion of the actual microhabitat elevation with that of the nearest mapped human habitation. The altitude of the southernmost record in Guachinango, Jalisco, given as $1250 \mathrm{~m}$ by MontesOntiveros and Ponce-Campos (2006), is actually $1467 \mathrm{~m}$; there is no elevation of $1250 \mathrm{~m}$ anywhere within $30 \mathrm{~km}$ of Guachinango.

To the west of Yecora, Sonora (28.37 N, $108.93 \mathrm{~W}$, alt. $1576 \mathrm{~m}$ ), a number of specimens have been found by naturalists since 1983 , most records remaining unpublished. Some of these localities are at elevations exceeding 1600 $\mathrm{m}$ (J. Reyes Velasco, pers. comm.). Other species of widely distributed amphibians and reptiles from the immediate area of a site near Yecora where a female Spotted Box Turtle was found beneath a large rock in summer 2005 include the Sonora Mud Turtle, Kinosternon sonoriense, and Ambystoma rosaceum, Hyla arenicolor, Rana chiricahuensis, $R$. tarahumarae, Gastrophyrne olivacea, Sceloporus clarkii, S. jarrovii, Eumeces callicephalus, Aspidocelis opatae, Thamnophis cyrtopsis, T. melanogaster, Senticolis triasipis, and Lampropeltis pyromelana (T. Burkhardt, pers. comm.).

Next to nothing is known of the ecology of T. nelsoni. Lemos-Espinal (2005) surmised credibly that these turtles are insectivorous, having observed numerous insects larger than $1 \mathrm{~cm}$ in length wherever he found turtles in southwestern Chihuahua. A few freshly captured specimens in Nayarit were offered a variety of fruits and invertebrates, but only two turtles consumed one beetle each (Minx 2009). The same author noted fresh scat containing insect parts and nematodes. The beak of the male specimen found in the Río Aros basin by O'Brien et al. (2006) bore crimson stains, suggesting that it had been feeding on the fruit of the organ pipe cactus Stenocereus thurberi. 
Reproduction. - Of 20 T. nelsoni females collected and dissected in the month of July by Milstead and Tinkle (1967) to determine their reproductive status, 19 were found to contain 1-4 oviducal eggs (usually 3 , the mean clutch size being 2.7). Averaging 47 x $27 \mathrm{~mm}$, the eggs were distinctly larger than those of $T$. ornata in Kansas measured by Legler (1960). However, the mean clutch size of T. o. ornata is known to vary from 3.5 to 4.7 , which could account for their smaller eggs (Nieuwolt-Dacanay 1997). In contrast, 77 T. o. luteola females from Socorro County, New Mexico, produced smaller clutches (mean size 2.68), much closer to the mean of the T. nelsoni sample. The average width of 203 T. o. luteola eggs was $26.6 \mathrm{~mm}$ (Nieuwoldt-Dacanay 1997), likewise approximating that of the small sample of T. nelsoni eggs. Although no mensural data on neonates are provided by that author, the CL of 11 neonate T. o. luteola from natural nests and from eggs incubated artificially varied from 35.6-39.9 $\mathrm{mm}$, with an average of $38.1 \mathrm{~mm}$ (I. Murray, unpubl. data from Otero and Doña Ana Counties, New Mexico). None of these bore a measurable growth ring when measured, while the smallest juvenile which did so measured $37.9 \mathrm{~mm}$ CL. Thus the estimated size at hatching of the Chihuahua post-hatchling T. nelsoni, just over $35 \mathrm{~mm} \mathrm{CL}$, compares credibly to that of T. o. luteola. In contrast, Dodd (2001) provided $28.8 \mathrm{~mm}$ as the CL of a neonate T.o.ornata found in the month of May in Indiana, Legler (1960) gave CL figures of $29.9 \mathrm{~mm}$ and $33.1 \mathrm{~mm}$ of two hatchlings found in October 1955 in Douglas Co., Kansas, and Ernst et al. (1994) declared the approximate CL of hatchling T. ornata (no locality specified) to be $30 \mathrm{~mm}$.

Milstead and Tinkle (1967) surmised that oviposition in T.nelsoni took place at the beginning of the rainy season, and that the eggs hatched towards the end of the rainy season, when food for them would be abundant. Concerning the nesting period, Minx (2009) concurs, and suspects that both mating and oviposition in Nayarit take place almost concurrently following the appearance of $T$. nelsoni in response to drenching rains. No natural nests of the species have been found, nor is successful captive reproduction known. Anecdotal evidence for parapatric T. o. luteola suggests that hatchlings sometimes emerge towards the end of the summer activity season from eggs laid in June or July, whereas others overwinter within the nest and appear on the surface after the first of the following monsoon rains (Murray, unpubl. data). A single case of hybridization between a female T. nelsoni and a male T. o. ornata has been reported (Buskirk 2002).

Population Status. - As regarding its ecology, the population status of Terrapene nelsoni remains unknown. Threats to its survival can only be presumed, but its rugged and remote habitat formerly has favored little human activity except mining. The difficulty of accessing the Spotted Box Turtle's mountainous habitat was first emphasized by Bogert and Oliver (1945). Currently the sparsely populated region may lend itself to little economic incursion except for the cultivation and trafficking of opium products and/ or cannabis for the international drug trade. The species may have a disjunct occurrence but seems to be present at least occasionally in high densities (Lemos-Espinal 2005; Minx 2009).

Conservation Measures Taken. - No specific conservation measures have been taken on behalf of this species. The IUCN Red List has classified it as Data Deficient since 1996. It is included on CITES Appendix II as a member of the genus Terrapene. In Mexico it is listed as Pr. (2.2.4, Subject to Special Protection). The precise textual explanation of this designation is (authors' translation): "Those [species] which could find themselves threatened by factors negatively impacting their viability, determining the need to support their recovery and conservation, or the recovery and conservation of populations of associated species (This category may include the IUCN's categories of lowest risk)."

Terrapene nelsoni is present in two large and two small protected areas in the northern part of its range, the Los Pavos Northern Jaguar Preserve (Sonora) (O’Brien et al. 2006), the Área de Protección de Flora y Fauna Sierra de Álamos y Río Cuchujaqui (Sonora), the Parque Natural Barranca del Cobre (Chihuahua), and the Parque Nacional Cascada de Basaseachic (Chihuahua). At least in the second and third of these, there has been significant human disturbance for generations in the more accessible areas.

Because the region inhabited by this species is quite vast, it seems questionable to have given it the conservation priority rating of APR 2 (TFTSG 1989). Only two other of 16 species placed in this category likewise have such a geographically extensive range, and in both cases the habitat is more accessible and thus more vulnerable to human interference than is that of T. nelsoni.

Conservation Measures Proposed. - Any rangewide survey, the desirability of which has been advocated (TFTSG 1989), which might yield published or otherwise accessible information concerning precise locations of populations of this species, could lead to their clandestine collection and removal for the international pet trade. Monitoring for the possibility of such a trade developing would be advisable.

Captive Husbandry. - No published work on this subject exists with regard to T. nelsoni. A female specimen brought to San Francisco, California from Álamos, Sonora, in 1968 survived for 6 years (Buskirk 2002). For the following information, the author is indebted to Stéphane Poulin, Curator of Herpetology, Arizona Sonora Desert Museum (ASDM), Tucson, Arizona. The longest surviving specimen of this species, an adult female, has been kept by the ASDM for 27 years since 1984. That it was originally in an emaciated state suggests that it had endured captivity for some time after having been collected in thornscrub habitat near Choquincahui, Sonora, near the type locality of $T . n$. klauberi. The turtle's housing has varied since its acquisition, having lived both indoors and out, in isolation or in the company of other reptile species occurring within its range, as at present, in a cage inside the Herpetology building. This 
cage contains both natural and artificial burrows (PVC pipes) in deep, sandy soil, providing refuge for the turtle, and for the large lizards sharing the habitat. The turtle feeds upon crickets, nightcrawlers, small rodents, and salad (90\% kale, $10 \%$ parsley and/or cilantro).

Other Spotted Box Turtles, including males, had been housed with this female until their deaths. Their longevity varied from only 3 months (a female) to 3 years and to 5.5 years ( 2 males). Efforts to breed the surviving female with either male included overwintering her some years, but without success. All captives had harbored parasites (flagellates) at the time of acquisition, for which they were medicated appropriately and successively. The surviving female is no longer deliberately overwintered, but usually becomes dormant (and unfindable) for varying periods both in summer, and during autumn and early winter. Photographs of this female appear in the works of Franklin and Killpack (2009) and Stone (2007).

A number of living T. nelsoni adults, obtained at the type locality by Minx in July 1987, were brought back to the USA, and some of the females subsequently laid eggs. Only one egg hatched, and the hatchling did not survive (Buskirk 2002). The remains of the deceased hatchling are preserved in the Chelonian Research Institute, Oviedo, Florida.

Current Research. - There are no current investigations focusing on T. nelsoni, only the incidental finding of specimens, sometimes reported in print or on the internet. The physical difficulty of maintaining a campsite during the monsoon season, in precipitous, isolated terrain, in which human company is likely to include affiliates of Mexican drug cartels, combine to discourage such efforts. Nonetheless, O'Brien et al.(2006) declared: “Our study area centered on the Los Pavos Northern Jaguar Preserve could provide an ideal conservation area in which to more closely study the life history of spotted box turtles at or near the northern extent of their range."

Acknowledgments. - Several people provided vital assistance in compiling this account, only one of whom has been duly acknowledged, above. Most of these individuals provided photographic material as well. These others are Pat Minx, Tim Burkhardt, Matt Cage, Young Cage, Sky Jacobs, Vladimir Dinets, Ian Murray, James Poindexter, George Zug, Hans Meier, Richard Bartlett, Craig Ivanyi, Claude Nottebaert, and Jacobo Reyes Velasco.

\section{LITERATURE CITED}

AnONYMous. 2001. Proyecto de Modificación a la Norma Oficial Mexicana NOM-059-SEMARNAT-2001, Protección ambientalEspecies nativas de México de flora y fauna silvestres-Categorías de riesgo y especificaciones para su inclusión, exclusión o cambio-Lista de especies en riesgo.

Anonymous. 2009. Enciclopedia de los Municipios de México, INFEDEM, Gobierno del Estado de Nayarit.

BickHAM,J.W.,LAmb, T.,MinX,P., ANd PATton,J.C. 1996. Molecular systematics of the genus Clemmys and the intergeneric relationships of emydid turtles. Herpetologica 52(1):89-97.
Bogert, C.M. 1943. A new box turtle from southeastern Sonora, Mexico. American Museum Novitates 1226: 1-7.

Bogert, C.M. AND Oliver, J.A. 1945. A preliminary analysis of the herpetofauna of Sonora. Bulletin of the American Museum of Natural History 83(6):297-426.

Buhlmann, K.A., Akre, T.S.B., Iverson, J.B., Karapatakis, D., Mittermeier, R.A., Georges, A., Rhodin, A.G.J., van DiJK, P.P., AND GibBons, J.W. 2009. A global analysis of tortoise and freshwater turtle distributions with identification of priority conservation areas. Chelonian Conservation and Biology 8(2):116-149.

BuskiRK, J. 2002. The mysterious Mexican spotted box turtle, Terrapene nelsoni Stejneger, 1925. Radiata 11(1):3-11.

Devaux, B. and Buskirk, J. 2001. Les Terrapene. La Tortue 55:14-33.

Ditmars, R.L. 1934. A review of the box turtles. Zoologica 17(1):1-45.

Dinets, V. And Polechna, P.J. undated. http://dinets.travel.ru/ blackjaguar.htm

DodD, K. 2001. North American Box Turtles, A History. Norman: University of Oklahoma Press, $231 \mathrm{pp}$.

ERnst, C.H., Lovich, J.E., ANd Barbour, R.W. 1994. Turtles of the United States and Canada. Washington, DC: Smithsonian Institution, $578 \mathrm{pp}$.

Franklin, C.J. and Killpack, D.C. 2009. The Complete North American Box Turtle. Rodeo, NM: ECO Herpetological Publishing, $242 \mathrm{pp}$.

Goldman, E.A. 1951. Biological Investigations in Mexico. Smithsonian Miscellaneous Collections, No. 115, 476 pp.

Hardy, L.H. AND MCDiarmid, R.W. 1969. The Amphibians and Reptiles of Sinaloa, México. University of Kansas, 251 pp.

Iverson, J.B. 1992. A Revised Checklist with Distribution Maps of the Turtles of the World. Richmond, IN: Privately printed, $363 \mathrm{pp}$.

LEGLER, J.M. 1960. Natural history of the ornate box turtle, Terrapene ornata ornata Agassiz. University of Kansas Publications Museum of Natural History 11:527-669.

Lemos-Espinal, J.A. 2005. Anfibios y reptiles de la Sierra Tarahumara. Universidad Nacional Autónoma México, Facultad de Estudios Superiores Iztacala, Informe final SNIB-CONABIO proyecto No. X004, 50 pp.

LEMOS-EsPINAL,J.A. ANDSMITH,H.M. 2002.Geographic distribution. Terrapene nelsoni klauberi. Herpetological Review 32:274.

Lemos-Espinal, J.A., SMith, H.M., AND ChISZAR, D. 2004. Introducción a los anfibios y reptiles del estado de Chihuahua. Universidad Nacional Autónoma México, CONABIO, 128 pp.

Lovich, J.E., Laemmerzahl, A.F., Ernst, C.H., And McBreen, J.F. 1991. Relationships among turtles of the genus Clemmys (Reptilia, Testudines, Emydidae) as suggested by plastron scute morphology. Zoologica Scripta 20(4):425-429.

Mertens, R. and H. Wermuth. 1955. Die rezenten Schildkröten, Krokodile, und Brückenechsen.Zoologische Jahrbuch Abteilung Allg. Syst. 85(5):323-440.

Milstead, W.W. 1969. Studies on the evolution of the box turtles (genus Terrapene). Bulletin Florida State Museum of Biological Sciences 14(1):1-113.

Milstead, W.W. and Tinkle, D.W. 1967. Terrapene of western Mexico, with comments on the species groups in the genus. Copeia 1967(1):180-187.

Minx, P. 1996. Phylogenetic relationships among the box turtles, genus Terrapene. Herpetologica 52(4):584-597.

MinX, P. 2009. 1987 Trip to La Mesa Nayarit. http://sites.google. com/site/tnelsoni1987/1987-trip-to-la-mesa-nayarit. 
MocQuard, M.F. 1899. Reptiles et batrachians recueillis au Méxique par M. Léon Diguet en 1896 et 1897. Bulletin de la Société Philomatique 9(1)4:154-169.

Montes-Ontiveros, O. and Ponce-Campos, P. 2006. Geographic distribution. Terrapene nelsoni nelsoni. Herpetological Review 37:239.

Myers, G.S. 1945. A third record of the Sonoran box turtle. Copeia 1945(3):172.

Nieuwolt-Dacanay, P.M. 1997. Reproduction in the Western Box Turtle, Terrapene ornata luteola. Copeia 1997(4):819-826.

O'Brien, C.,Flesch,A.D.,W allace,E., Bogan, M., Carrillo-PerCASTEGUI, S.E., JACOBS, S., AND VAN RIPER, C., III. 2006.Biological Inventory of the Río Aros, Sonora, Mexico: A River Unknown. Final Report to T\&E, Inc., 57 pp. http://www.aaronflesch.com/ Publications/Reports/O'Brien,\%20Flesch,et\%20al.\%20\%20 \%202006.\%20\%20Rio\%20Aros\%20Inventory.pdf

Ponce-Campos, P. And Buskirk, J. 2010. Geographic Distribution. Terrapene nelsoni. Herpetological Review 41:510.

SHaw, C.E. 1952. Sexual dimorphism in Terrapene klauberi and the relationship of $T$. nelsoni to T. klauberi. Herpetologica 8:39-41.

Smith, H.M. And Smith, R.B. 1979. Synopsis of the Herpetofauna of Mexico. Vol. VI. Guide to Mexican Turtles. Bibliographic Ad- dendum III. North Bennington, VT: John Johnson, 1044 pp. STEJNEGER, L. 1925. New species of American turtles. Journal of the Washington Academy of Science 15(20):463.

Stone, L.M. 2007. Box turtles. Nature Watch, Lerner Publications Co., 48 pp.

TFTSG. 1989. Status survey of the spotted box turtle (Terrapene nelsoni) in western Mexico. Tortoise and Freshwater Turtles: An Action Plan for their Conservation. Gland, Switzerland: IUCN/ SSC Tortoise and Freshwater Turtle Specialist Group, 47 pp.

Wermuth, H. ANd Mertens, R. 1961. Schildkröten, Krokodile, Brückenechsen. Jena: Gustav Fischer Verlag, 422 pp.

\section{Citation Format for this Account:}

Buskirk, J.R. And Ponce-CAmpos, P. 2011. Terrapene nelsoni Stejneger 1925 - Spotted Box Turtle, Tortuga de Chispitas, Tortuga de Monte.In: Rhodin,A.G.J.,Pritchard,P.C.H., van Dijk,P.P., Saumure, R.A., Buhlmann, K.A., Iverson, J.B., and Mittermeier, R.A. (Eds.). Conservation Biology of Freshwater Turtles and Tortoises: A Compilation Project of the IUCN/SSC Tortoise and Freshwater Turtle Specialist Group. Chelonian Research Monographs No. 5, pp. 060.1-060.9, doi:10.3854/crm.5.060.nelsoni.v1.2011, http:// www.iucn-tftsg.org/cbftt/. 